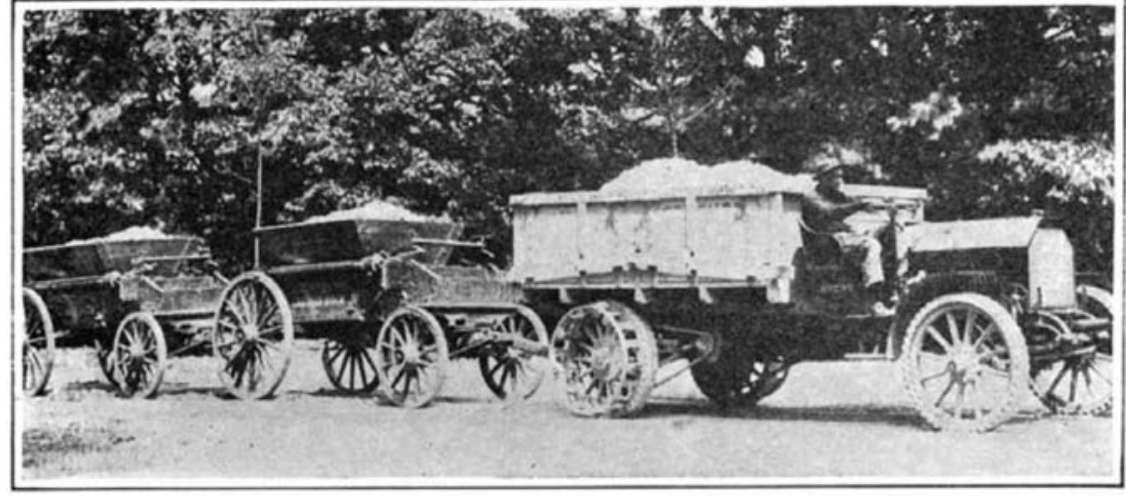

Hauling crushed rock with a motor truck and at
the same time pulling two trailers over dirt.

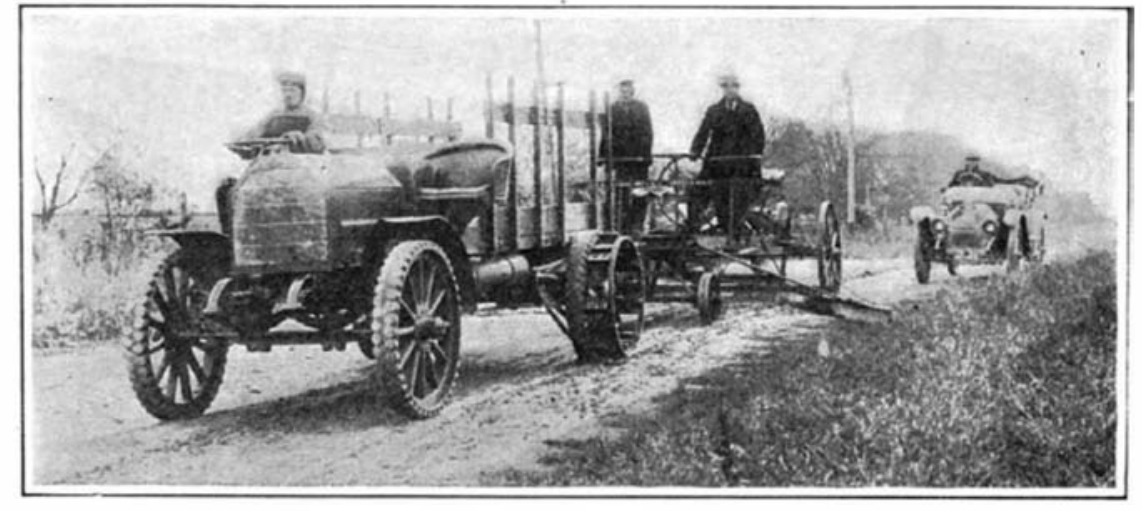

Motor truck with platform stakes for hauling lumber, pulling grader and drag.

\title{
Building Good Roads by Auto Power
}

A Cheap Way of Improving Highways

By Rex Beresford

THE monumental waste and inefficiency 1 of the old time road district with its supervisor, and the "working out" of the road taxes in a sort of picnic, rather than in "fear and trembling" as salvation is said to be alone attained, has been largely abandoned. Efficiency marks the new plans. Men who know something about road building are being employed by townships and counties as road engineers or as "superintendents," where the term "engineer" rouses distrust in a farming populace. New machinery and new methods are being adopted at every turn. In fact, the 2,151,000 miles of roads and "nea roads" that we have in rural United States are, as has been expressed by one person of unknown nationality, "now on the highway of improvement."

"The automobile," still quoting from the same gentleman "has been a potent factor in this improvement, in both directions." It has proved a great stimulus for the good roads idea in the towns and cities, and among the farmers who own autos. On the other hand, it has created a good deal of opposition to the whole scheme of road improvement among farmers who do not own machines.

The introduction of automobiles has worked toward road improvement. There have been a good many cases where the automobile has lieen more than a moral agent in that direction. It has been hitched to a road drag and made to make smooth the rough places itself. To its credit be it said, that where the automolile has been put to such work it has done well and quickly what would otherwise have been left undone.

The split-log drag has been turned over to very good use by motor works located at Lansing, Mich. It occurred to the management that, while giving their cars the usual road tests, a double purpose could be served and the testing cars used to improve the conditions of the roads over which they passed. To this end, a split-log drag was contrived and attached to each car as it went forth to its test.

The experiment worked out admirably, as evidenced by the accompanying illus tration, resulting in a vast improvement in the neighborhood and an economy to the borough. The work was accomplished without any expense of power or laborsimply by using the energy which formerly had been used exclusively for testing purposes.

It has been left to the big brother of the automobile, the motor truck, to turn seriously to the task of road building and road maintenance. So far the truck has heen remarkably successful in road work. Especially is this true of the trucks fitted for traction work in pulling trailers, road graders. road drags, etc., as well as for hauling road and bridge construction materials on their own bodies.

Since the "picnic system" of working roads has gone out of vogue it has been hard to find teams ind drivers enongli to do the work that was absolutely necessitry

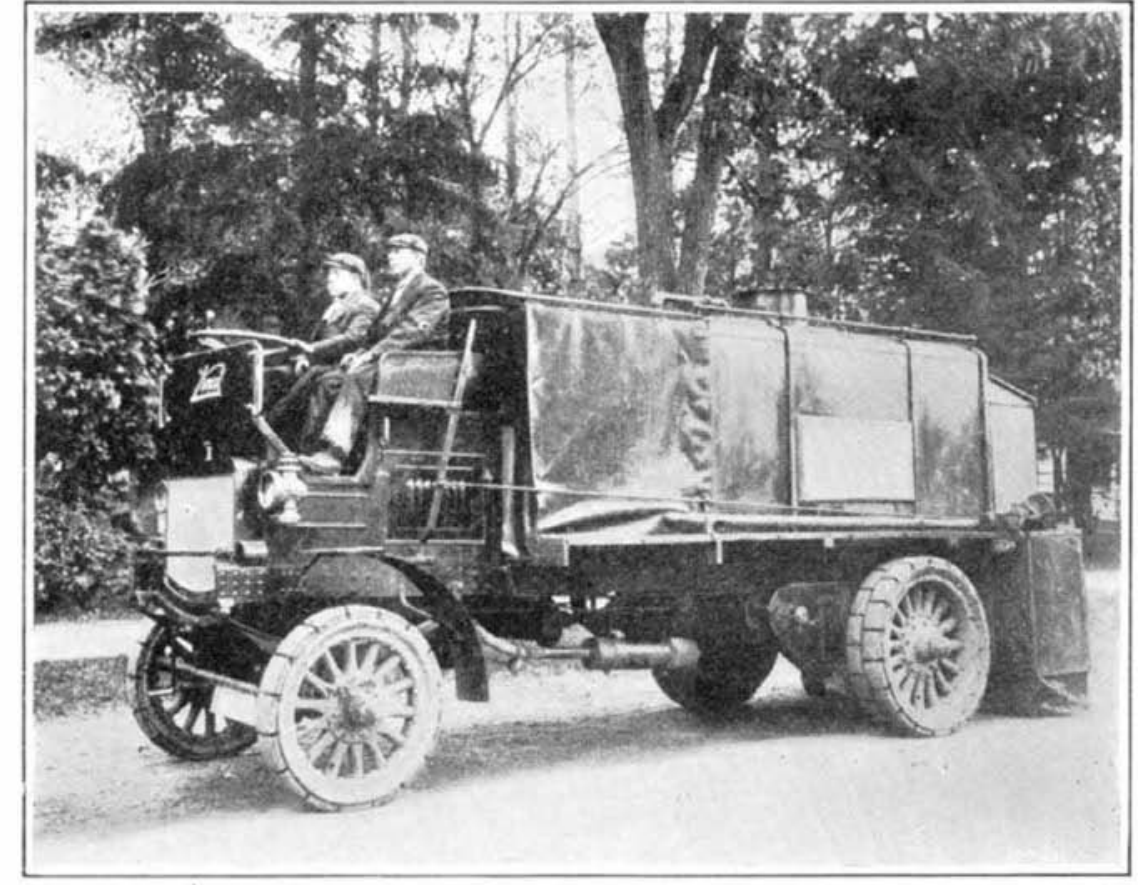

A five-ton motor truck used for road oiling near Worcester, Mass.

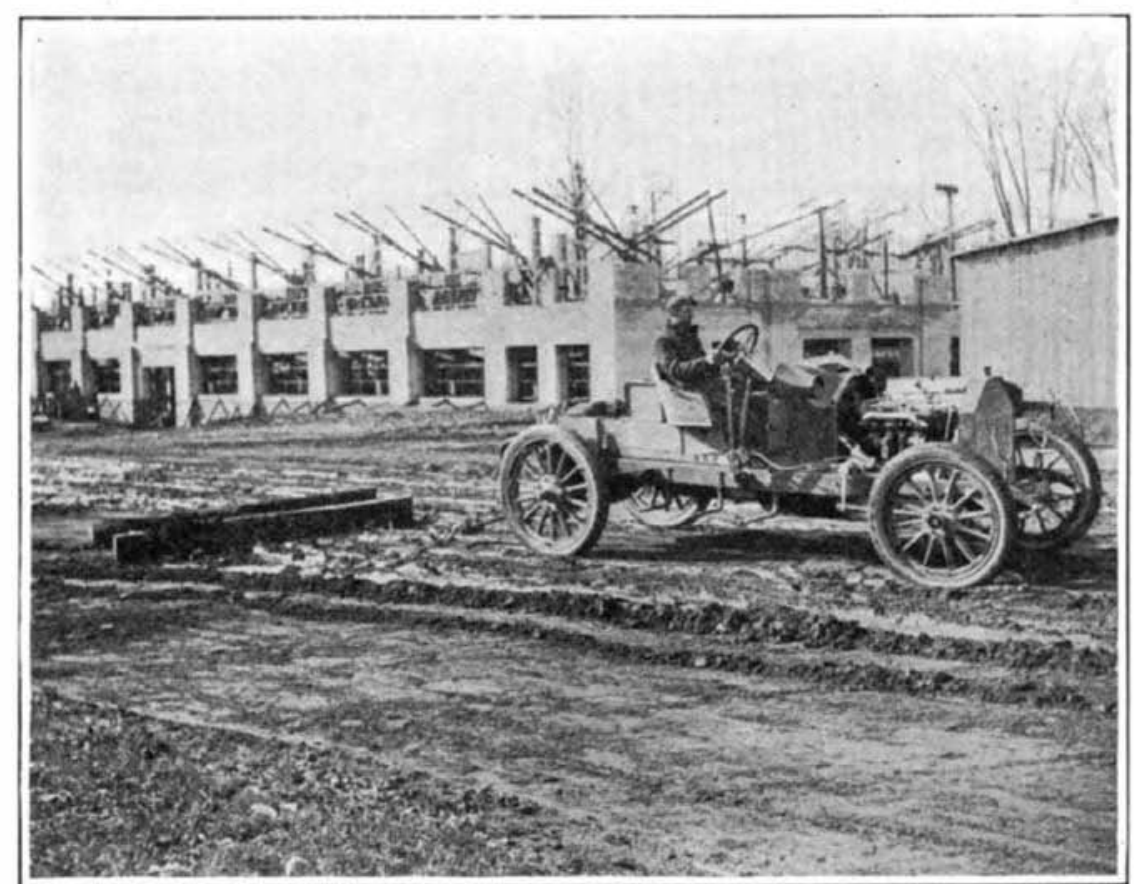

An automobile using the split-log drag to make good roads.

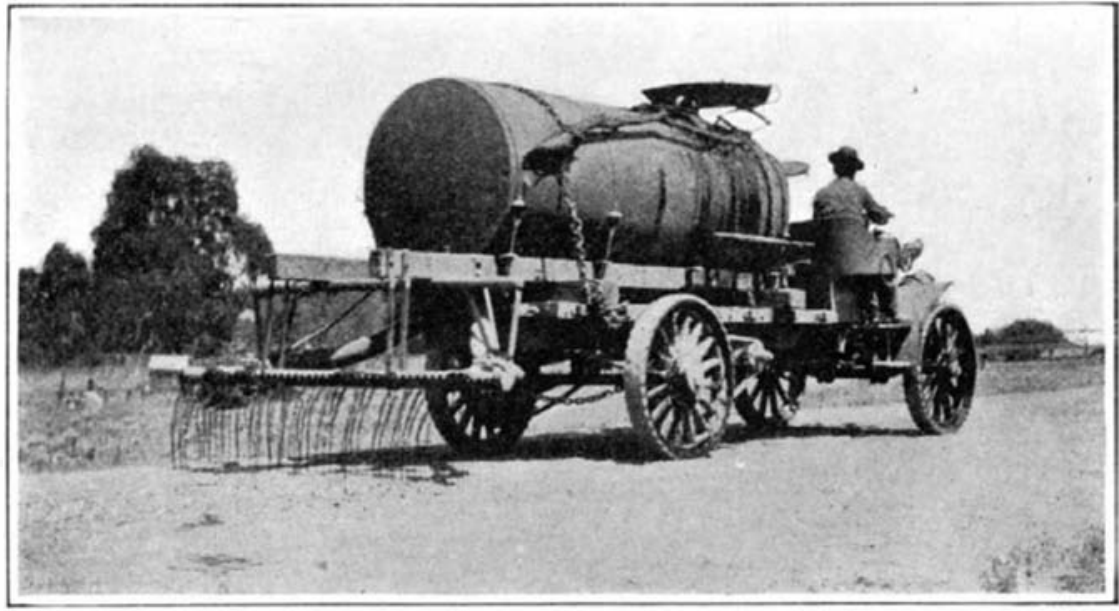

This truck hauls oil regularly every day. On Sundays it takes the ball team on trips to neighboring towns. to keep the roads passable, without trying to start anything new in the way of road improvement. It takes eight horses and from two to four drivers, besides the man to operate the machine, to handle the ordinary blade grader such as is in common use all over the country where dirt roads are the rule (and that constitutes something over 2,000,000 miles of roads). It is next to impossible to hire a team without hiring a driver too, and a team and driver cost from $\$ 250$ to $\$ 5.00$ a day, depending somewhat on the locality and the demand for labor. At any rate, a grading outfit is operated by horse-power at an expense of from $\$ 12.00$ to $\$ 16.00$ or more per day, not counting the salary of the man who handles the grader.

Such an outfit does extremely well if it goes over a stretch of a mile and a half or two miles, cleans out the ditches, rakes the sod, trash, and a little bit of dirt into the middle of the road and deposits it there in bumps and hummocks slough, all in one day. In a good many instances it has been impossible to get teams and men when the roads were in fit condition to be worked. Seeding time, corn planting and plowing all come just alout the time the roads need the most attention. 'The farmer in the corn belt, who will leave a corn field that needs him in order to work roads at ordinary wages, is an exception. Moreover, with such systems of working the roads, it has been found that it takes on an average, better than seventy-five per cent of the whole fund available to a community, just to keep the roads patched up and the ditches half cleaned out, leaving a scant twenty-five per cent to be spent in bridges, permanent roads and real road improvement.

All this is the reason, or rather the collection of reasons why the trustees of Hooper Township out in Dodge County, Nebraska, who had seen a motor truck pulling a three-gang plow in sod, got the notion that it would be useful hitched ahead of a road grader just as well as ahead of a plow. They investigated, and finally bought a three-ton truck, fitted with a special perforated cast-steel rim wheel with wood plug tires, and an extension rim for the rear wheels for use in soft ground and in hard pulling. They hitched it to an ordinary big blade grader such as is usually pulled by eight or ten horses. The truck had a forty-five horsepower motor, and it pulled the grader in good shape in any sort of ground that was fit to be worked. It hauled the machine at from four to six miles an hour without stopping to rest. and it did it with but one driver, and one man on the grader. It went any place that the lig teams could go, and it turned and backed and got into the corners and ditches much more easily than the "strung out" eighthorse teams ever did. The truck and one grader did as much work as two machines with teams, and did it all with about (Concluded on poyse 25it.) 


\section{The Open Doors}

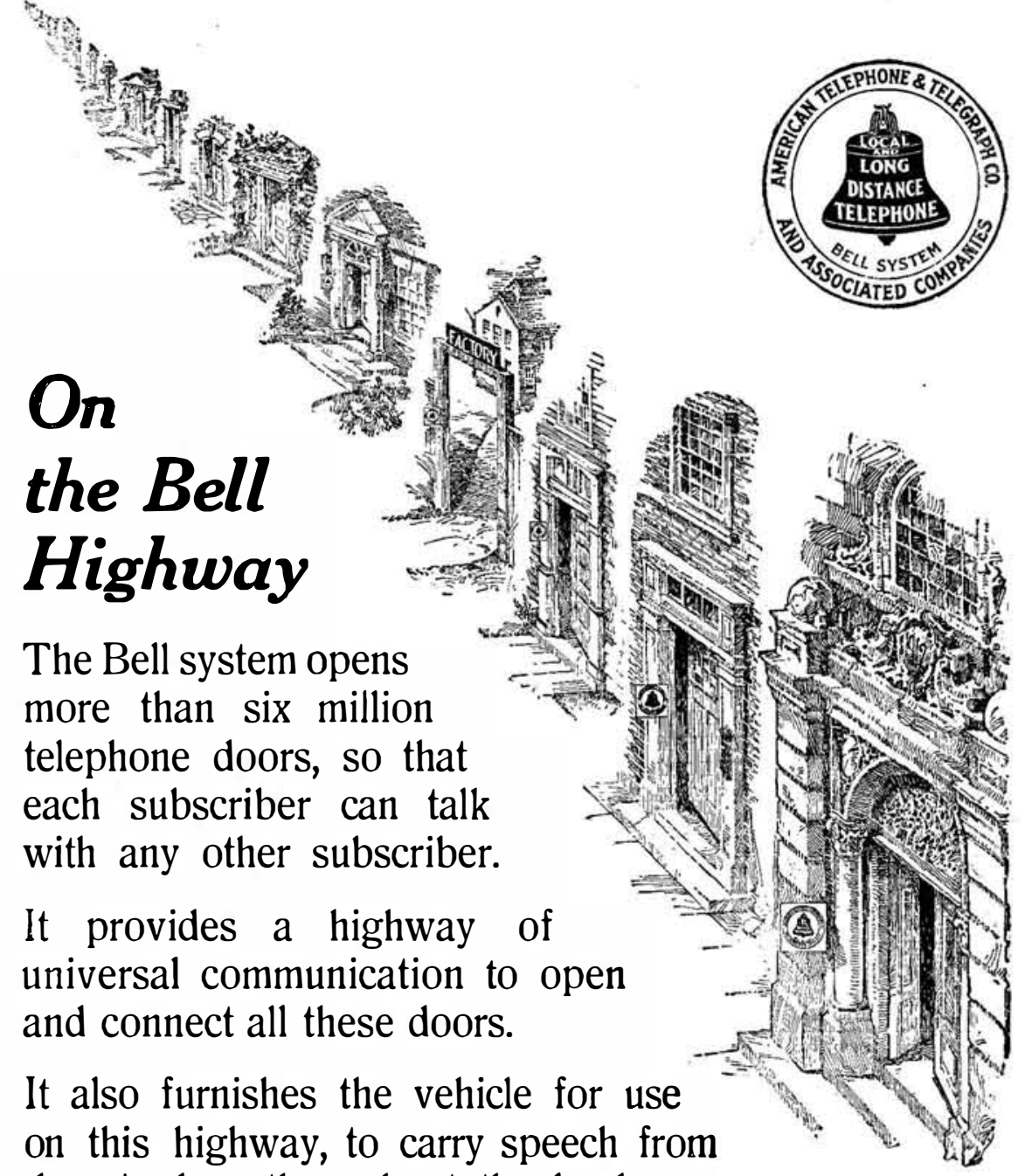

door to door throughout the land.

The Bell highway is used daily by more than twenty million people-all telephone neighbors-by means of universal service.

\section{American Telephone and Telegraph Company AND ASSOCIATED COMPANIES}

\section{One Policy One System Universal Service}

\section{SCIENCE IN THE IDEAL HOME}

The April Magazine Number of the Scientific American Issue of April 13, 1912

Scientific management, with its close attention to important details, is not confined to the shops or the industries, but is applicable to all lines of human activity. Last year, Frank B. Gilbreth, the well known Efficiency Engineer, published a book on "Motion Study," and to illustrate his argument he showed how, by attention to seemingly unimportant details, and the elimination of wasted effort in awkward and useless motions, he had actually increased the efficiency of brick-layers many-fold. Although this book made a sensation and attracted widespread attention, its value was by no means fully realized because many readers took it for granted that it pertained solely to the building trades. But the principles that Mr. Gilbreth outlined have a very broad application, as evidence of which he is going to explain to the readers of the Scientific American how Motion Study may be applied in the home to relieve the drudgery of housework. The article is not to be made up of broad generalizations, but will be fully illustred with specific examples of actual conditions

One of the most serious problems that the home presents to the engineer, particularly the detached villa or country house, is the sanitary disposa of sewage. The problem is more complicated than that of the municipality, but much deep study has been devoted to the subject, and excellent methods have now been developed for the purification of the sewage and the destruction of bacteria. This subject will be treated very thoroughly by Dr. Jacolyn Van Vliet Manning.

There is an experiment station in Colonia, New Jersey, where domestic engineering is being studied scientifically. Here all manner of labor-saving devices are subject to practical and impartial tests. It is the only station of its kind in the world. Mary Pattison who is a pupil of Frederick W. Taylor and Harrington Emerson the well-known efficiency engineers, is going to tell of her interesting work there in the April Magazine Number.

In addition to these articles the number will contain the usual variety of material, including an article by William Atherton DuPuy on the Woman Inventor.
Building Good Roads by Auto Power Concluded from page 234.)

half the men it took for one outfit with horses. It cost from $\$ 2.50$ to $\$ 3.00$ a day in gasoline, oil, etc., to run the truck. Counting depreciation, interest, and re The driver's was not over $\$ .00$ a day. This would make a total cost of a day. This would make a total cost of not over day for teams to do one-half the work done by the truck.

The truck was used also for dragging roads with a heavy split log drag. It has covered better than fifty miles of road with the drag in three days time of ten hours each. Pulling two lighter drags it has finished twenty miles and better in a single day. The plan in this township is to use a headight on the truck. When the roads get ready after a rain or in the spring, the machine goes over the whole
township, running night and day till the township, running night and day till the job is done. With this scheme the townsmen are able to arag more roads than half a dozen men and teains could handle, and they get the road done at the right time. With the special wheels the roads are dry enough for the mach since found that the truck could have handled the work of at least two townships with almost equal ease, and at the same time have lessened the expense conthe truck and make it manage to earn its gasoline all the year round, grading, hauling bridge, culvert, and other road material and doing other work for the township. Besides, when it is not in use, At first there was a good deal of oppo sition to the purchase of the truck the citizens of the township, and a lot of complaint about it after it was bought. There are a few taxpayers there who still insist that "that contraption will bankrupt the township." But the majority of citizens of Hooper Township admit that the of Hooper Township admit that the there are still some men there who complain at the first cost, which in this case was $\$ 2,500$. Other townships are serilar truck. In several townships the question, "to buy or not to buy" a motor truck was the chief issue in the campaign last fall, and will be again. In the mean time Hooper Township has better dirt roads than ever before and at less cost. For than ever before and at less cost. For
that locality, the motor truck is solving he road problem.

Out in Boise, Idaho, the county commisioners have bought a truck like the one n use in Nebraska. Mr. E. A. Crawford, hairman of the Board of Commissioners, ays that they use their truck chiefly for hauling crushed rock for road construction. On a three-ton truck, pulling two trailers, they haul eight-ton loads up
grades of eight per cent or better. They have tried the truck out at other work also, and found it satisfactory, but have Wough hauling to do to keep it busy. With them the truck does the work of two to four teams and drivers, and does a firm in Jefferson, Iowa, has a conA firm in Jefferson, Iowa, has a con-
tract with the supervisors of two counties for supplying them with drain tile for culvert and road drainage work. It takes a lot of tile there too, but the firm is able to cover the whole two counties
with the motor truck, and keep the road with the motor truck, and keep the road
gangs supplied with tile. Incidentally gangs supplied with tile. Incidentally
the firm is making money for prices curthe firm is making money for prices cur-
rent for horse haulage are charged. The counties could save a good sum by owning their own truck.

Another truck engaged in road and bridge building is one owned by a lumber company of Grinnell, Iowa. This truck is busy most of the time hauling sand, rock past season it hauled a total of over 4,000 tons an average distance of over four miles. Some of these bridges were ten to They hauled right through the hottest weather, too, when horses couldn't work much because of the heat

A crushed stone company, of Cedar Rapids, Iowa, hauls crushed limestone for paving foundation, macadam, and other road and street work, and also uses its truck to pull trailers, hauling as high a ten tons on the truck and two trailers at one load.

On the roads about Jamestown, Calfornia, a motor truck is used to counteact the wearing and rutting effect of the

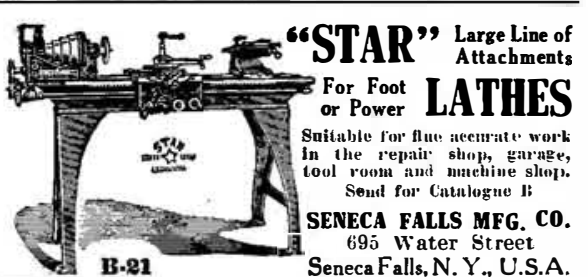

SEBASTIAN LATHES 9 to 15 Inch Swing
High Quality Low Prices Catalog Free This GRINDER

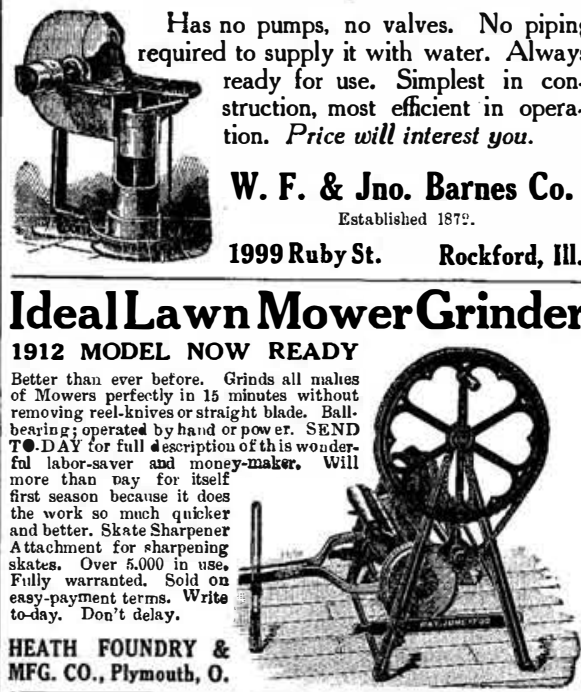

$\frac{\text { MFG. Co., Plymouth, } 0 .}{\text { You USE GRINDSTONES ? }}$

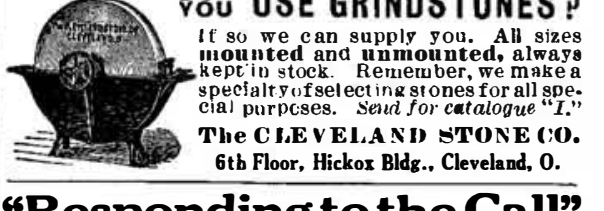

"Responding to the Call"
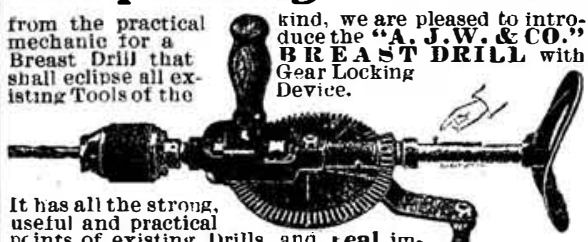

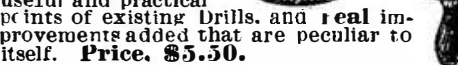

A. J. WILKINSON \& CO.. Machinery

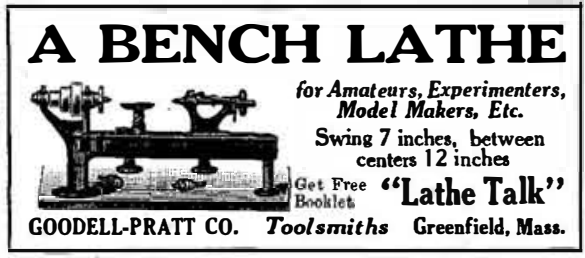

Experimental and Model Work

Antomobile and Marine Ensine Repairs.

QUEE

QUEENS CO. MACHINE WORKS
50-54 Summerfield St. EPICYCLIC TRAINS, which play an importan part in toothed gearing, are ably described in Scientific sale by Munn \& Co., Inc., and all newsdealers.

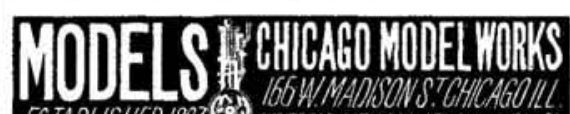

MASON'S NEW PAT. WHIP HOIST for Outrigger hoists. Faster than Elevators. and hoist
direct from teams. Saves handing at less expense. Manufactured by VOLNEY W. MASON \& CO., Inc. \begin{tabular}{l|l|l|}
\hline DIES, FINE TOOLS & SPECIAL \\
MAETAL SPECIALTIES & INVENTION \\
\hline
\end{tabular} MOORE \& CO., Indiana \& Frank.
hin Sls. Chicago. INVENTIONS
PERECTED Experimental \& Model Work Circular and Advice Free

Wm. Gardam \& Son, 82-86 Park Place, N. Y. THESCHWERDTLE STAMP GO. STEE STANPS LETTERS \& FIGURES. BRIDGEPORT GONN

G5 MACHINES Corliss Engines, Brewers The VILTER MFG. CO.

899 Clinton Street, Milwaukee, Wis. T.5. WANTED Tomanufactire METAL

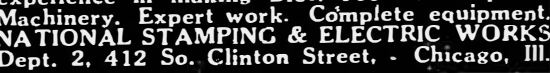

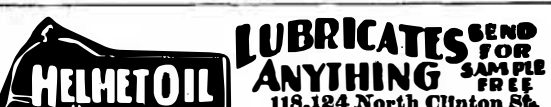

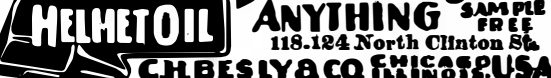




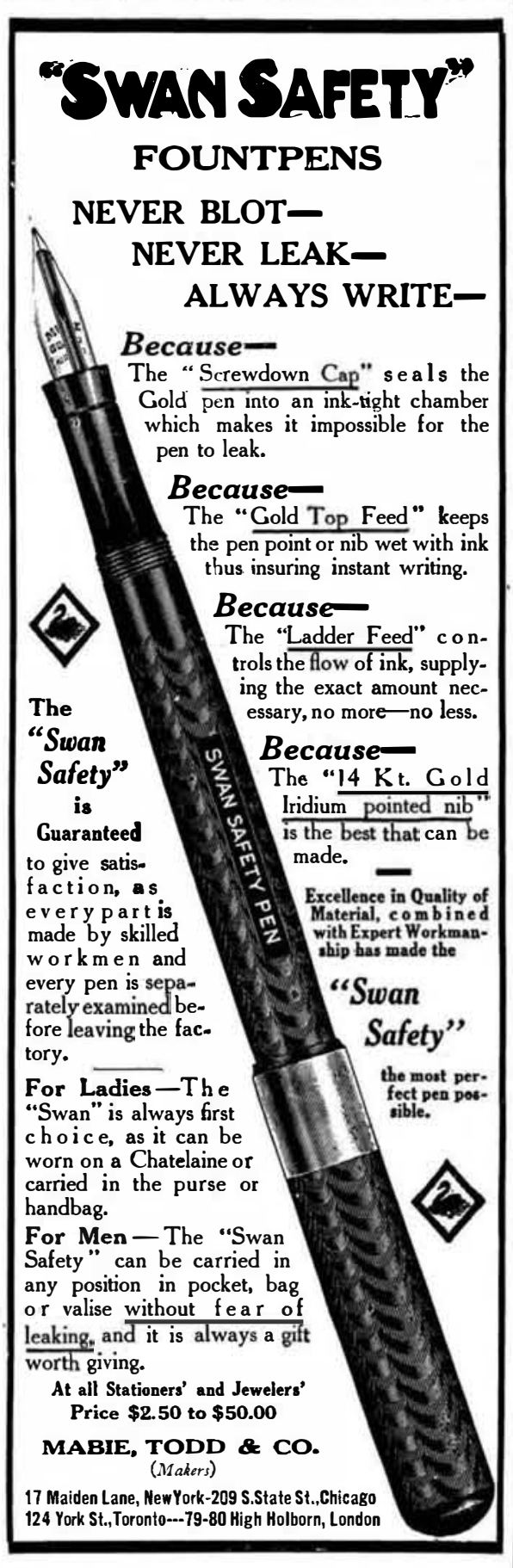

FREE SPECIMEN 'TABLOID' 'RYTOL' UNIVERSAL DEVELOPER ields perfect negatives, prints,
Send 2 cents to cover pastade.

BURROUGHS WELL COME A C C $0 ., 35$, Wrst 33re STREET, N.Y.T.
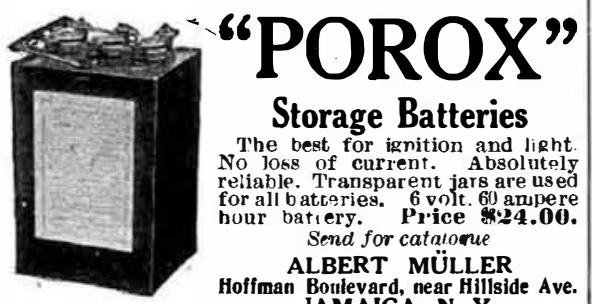

Storage Batteries

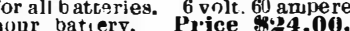
ALBRT MÜLLER
ALERT

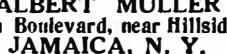

\section{구요 TYPEWRITERS Ath}

Visible Writers or otherw $1 / 4$ to $1 / 2$ MFRS. PRICES

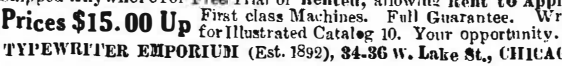

$7 \mathrm{HE}$ "Y and E' Blue Print Cabinet keeps 1000 prints flat, clean, smooth and instantly findable. Takes floor space of $33 / 4$ square feet. Booklet 2139 pictures fully.

Write for it.

\section{TAMMMLAN

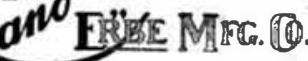

48 St. Paul St. Rochester, N. oiled road is not affected to any appreciable extent by the automobile wheels beroad, and the particles "stay put" oiled road, and the particles "stay put" instead of being swished and hauled around by the suction of the tires. With a big oil sprinkle" rapidly, one truck being able to cover a big territory. A truck makes good equally as well as a street sprinkler with just plain water, to lay the dust. Trucks are already in use in

\section{just such service.}

In St. Louis a paving company is using three-ton truck fitted with a special construction and repair work. The machine loads up the hot asphalt at the central plant, and delivers it at any distance up to fifteen or twenty miles still hot and ready to apply.

This is one of the good points of the motor truck for road work. A body fitted for hauling any sort of material can be supplied by most makers of trucks. Dump bodies for stone, sand, crushed rock, etc. lumber racks for hauling bridge material or plain platforms for grading work can be had according to the need. A dump truck and a couple of trailers can haul dirt from cuts to distant fills as fast as six or seven teams, where steam shovels There is almost no end to the uses to which such a machine may be put for furthering the cause of good roads. It has been used for running the cement mixer on jobs of concrete construction for culverts and bridges. One truck at least is fitted with a drive pulley which enables
it to do all sorts of work on the belt, such as running a small stone crusher, a cement ixer or a pile driver.

The use of the motor truck in roa building fits in particularly well with the one man, or one set of men can handle comparatively large territory in grada comparatively large territory in gradbridge and road drainage work, in road dragging, or in road repairing. The cost, where there is work enough for the truck to warrant the initial expense, is far less than where team power is used, both because of lessened labor and greater speed. The effectiveness of the road force is reased and the quality of the Of is bettered ly the use of the truck. the course, to outain all these results the truck used must be fitted for the job. It does not need to be very speedy nor motor, and the it must have a powerful traction. Moreover the operator must be a man of some skill and judgment. may cost a little more to hire such a man, but the better road that will result from his work will more than pay for the extra cost in his wage. Where bought for the purpose, and usedøwith reasonable proving a remarkably efficient "good

The Coleman du Pont Highway (Concluaed from page \$45.)

It is the author's belief that road building in the United States is in a very undeveloped state, and that within five or ten years we will find some mixture of tar or asphalt that can be mixed in a small percentage with the natural ground (sand, loam, clay or other material) and that in
this way we shall get a water-proof and this way we shall get a water-p
dust-proof road at a small cost.

Records, too, will be kept to see if the income from the extra width will in time pay an amount that will, first, maintain the road; second, pay interest on cost of
the road; third, pay the cost of the road, the road; third, pay the cost of the road,
and after this be a source of income that would pay all county or city taxes. The writer's opinion is that it will, and, if so, let the towns or counties or the Nation take enough ground, when building a new road, to ultimately make the road pay for itself, and allow the people who want to use the land to have it on 999 years lease, with certain conditions, at 4 per cent, the value of the land for purpose of paying rent to he adjusted every five years.

If the National highways could be built on this plan, it would only mean a temporary outlay of money by the Government, which would in a few years provide a source of income equal to that afforded by the tariff. This Gcvernment is necessarily becoming more and more expensive each year; therefore, the question of proportant one. By the plan suggested the money could be raised without injuring

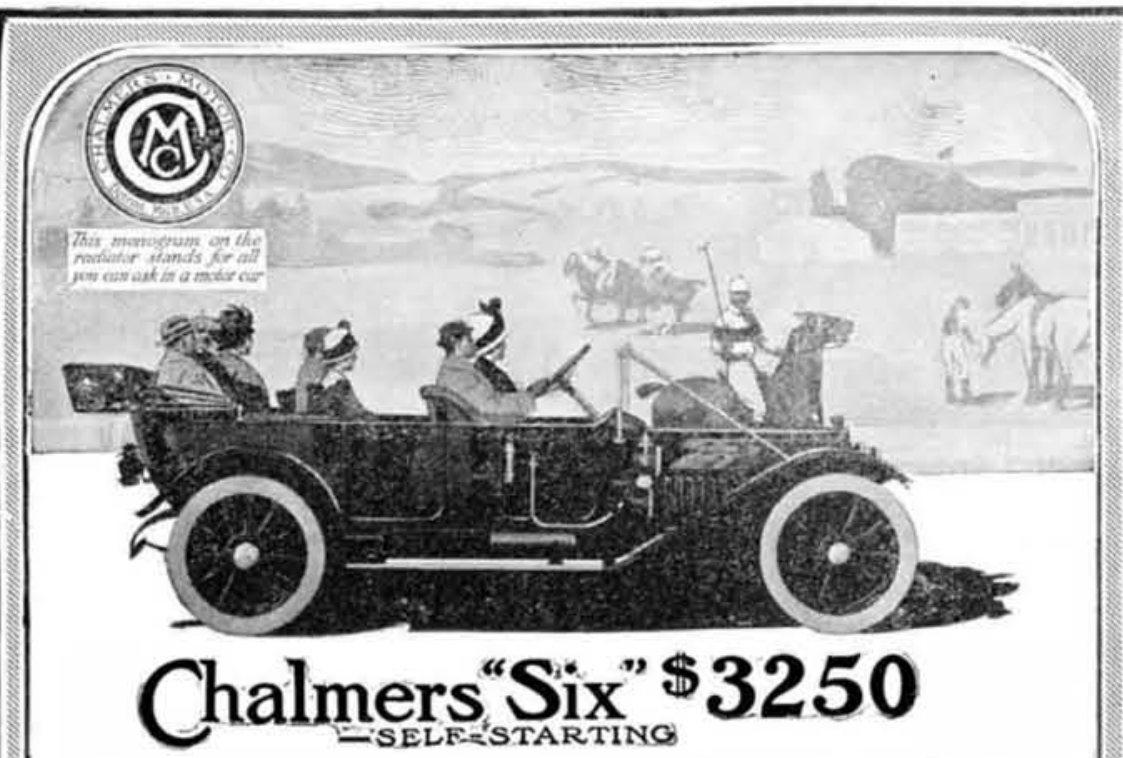

Offers you at a Reasonable Price the Acme of Motor Car Luxury

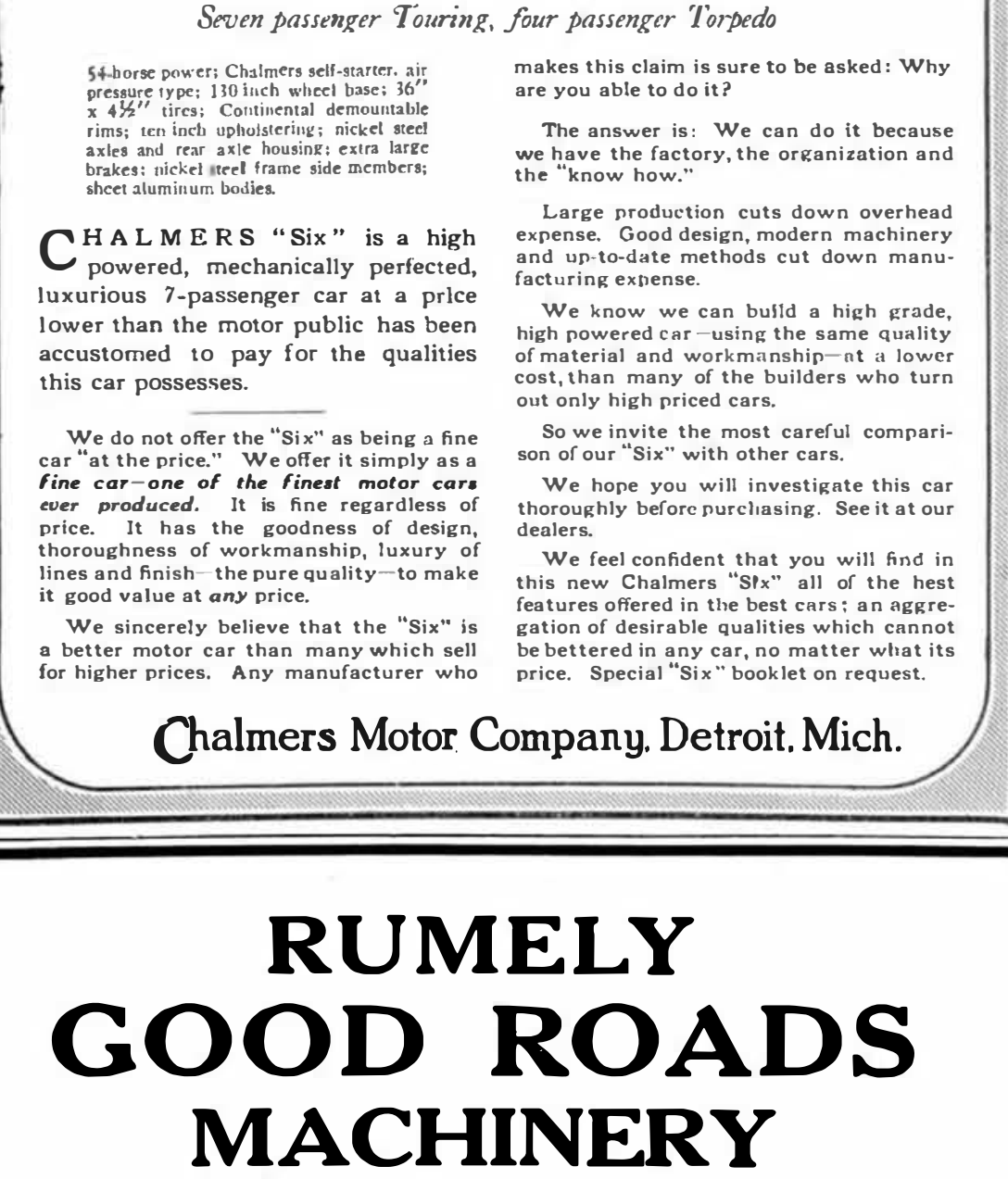

Q Rumely Oil and Steam Traction Engines are well fitted by power, weight and durable construction to meet the heavy demands of the road-builder-well adapted to heavy hauling, heavy grading and heavy work on the crusher

I The Tractor is the only to ctor that burns kerosene and heavier oils economically at all toads-under all conditions. It is very substantially built - easy to start and operate-furnished in three handy sizes of 15,25 and 30 tractive horsepower, both single and double-cylinder.

9 Our 20 h. p. Contractor's Special, and our 16, 20, 25 and 30 h. p. General Purpose and Plowing Tractors afford a satisfactory choice in double-cylinder, heavy-duty steam engines.

व We control exclusively the C. N. R. Patent Grader Attachment for Elevating Graders-operating the elevator by a positive drive direct from the engine countershaft. This device eliminates the wasteful, roundabout transmission of power through engine and grader drive wheels-adds 50 per cent. to the capacity without increasing either the power developed or the fuel consumed. It can be had only on Rumely Oil and Steam Tractors.

d Repairs for Rumely tractors are kept in complete stocks at thirty branch warehouses, guaranteeing prompt delivery.

(I The season for active work will open soon. Write us at once for an illustrated folder of special interest to contractors and highway commissioners. Ask, too, for a tractor catalog -oil or steam, as you prefer.

\section{RUMELY COMPANY}

22 Scio.Street 